\title{
Human Capital Spillovers and Local Unemployment
}

\author{
Jung Hyun $\mathrm{Choi}^{1}$ \\ Sol Price School of Public Policy \\ University of Southern California \\ Richard K. Green ${ }^{2}$ \\ Sol Price School of Public Policy \\ Marshall School of Business \\ University of Southern California
}

Preliminary and Incomplete

Please do not cite without permission

\begin{abstract}
This paper examines the magnitude of human capital spillovers on unemployment. Using both individual and metropolitan level data, we find that the adult population share of college graduates is negatively associated with the unemployment rate. More specifically, we find that those who reside in MSAs with higher shares of college graduates are more likely to be employed, even after controlling for individual, MSA and state level factors including individual's own education level. The likelihood of being unemployed falls further for the non-college graduates compared to the college graduates. We also find that MSAs with higher shares of college graduates have lower average unemployment rates. This education spillover is not transitory but is an important factor that explains long-term divergences in the MSA unemployment rates.
\end{abstract}

$J E L: J 21, \mathrm{~J} 64, \mathrm{R} 23$

${ }^{1}$ Email: choijung@usc.edu

2 Email:richardkg@usc.edu 


\section{Introduction}

This paper investigates the spillover effect of college education on individuals' unemployment. More specifically, the paper examines whether individuals who live in MSAs with greater shares of adult college graduates have lower propensity of being unemployed after controlling for individual, city and state specific characteristics. Furthermore, the paper tests whether the size of the human capital externality differs between those with and without a college degree.

While the existence of human capital externalities have gained interest for a long time, there have been relatively few empirical studies that estimate the magnitude of education spillover (Moretti, 2004a). A number of prior studies have looked at various proxies for local educational attainment to estimate the size of human capital spillover effects on wages after controlling for individual, MSA and state level factors (Rauch, 1993; Acemoglu and Angrist, 2000; Ciccone and Peri, 2006; Moretti, 2004b). Meanwhile, using plant level data, Morretti (2004a) investigates whether manufacturing firms are more productive in cities with higher fractions of collegeeducated workers. However, there has not been a study that looks at the relationship between the level of human capital in a city and individuals' employment status. Exploring this relationship is the heart of our research.

This paper contains several novel findings. First, the paper finds that individuals residing in $\mathrm{MSAs}^{3}$ with higher shares of college graduates are less likely to be unemployed. Furthermore, the size of the education spillover is greater for those without a college degree than it is for the college graduates. This result still hold when the individual level data is aggregated to the MSA level. In other words, MSAs with greater shares of college graduates have lower unemployment rate. Also, the size of this externality is larger for the non-college graduates compared to the college graduates.

\footnotetext{
${ }^{3}$ While some studies use state as their unit of analysis, we focus on MSAs instead of states. MSAs are closer approximations to individual job markets than states. States consist of multiple job markets, which may obscure the relationship between the unemployment rate and the explanatory variables For instance, Dallas, Houston and San Antonio are more or less individual jobs markets, while Texas is not.
} 
Second, the paper estimates long term MSA fixed effect coefficients for unemployment, and then examines how initial conditions might predict these fixed effects. Consistent with prior studies (see Elhorst 2003 for a review), we find a persistent divergence in the MSA unemployment rate. In other words, MSAs with high unemployment rates continues to have high unemployment rates, while the same holds for MSAs with low unemployment rates. The findings also show that the share of college graduates has a long-term effect on the MSA unemployment rate.

Finally, we test whether wage and house price differentials among MSAs can explain why MSA unemployment rates do not converge in the long run. We find evidence that high wages in low unemployment cities discourage firms from moving to MSAs with low unemployment rates, while high house prices in low unemployment cities discourage individuals from moving to MSAs with better job market conditions.

The remainder of this paper is organized as follows: Section II reviews existing literature and provides possible explanations for why high shares of college graduates may reduce unemployment. In section III, we describe the data and methodology. Section IV presents the empirical results and Section $\mathrm{V}$ concludes.

\section{Existing Literature}

This study is closely related to Enrico Morretti's two 2004 papers, which assess the magnitude of human capital spillovers. The intuition behind the first paper is from a well-known model by Roback $(1982,1988)$, which shows that firms are more productive in cities with higher overall levels of human capital due to agglomeration effects. Using plant level data, Morretti (2004a) confirms this hypothesis by finding that human capital, measured by the share of college graduates, spills over on productivity. The study shows that productivity of plants located in cities with high levels of human capital is greater than similar plants in cities with low levels of human capital. Since productive firms are likely to hire more workers, the agglomeration 
induced productivity increase may also affect unemployment. We hypothesize that the abundance of jobs in high human capital places will lead individuals to be more likely to be employed, even after controlling for individual education level.

In another study, Moretti (2004b) finds that workers in cities with higher shares of college graduates have higher wages. This positive effect on wages is greater for those without college degrees owing to both spillover and substitution effects. Not only do these workers benefit from the productivity gains, but they also obtain higher wage as non-college graduates are scarcer in MSAs with greater shares of college graduates. On the other hand, while college graduates also benefit from the spillover effect, greater competition among the college graduates may offset the spillover benefit. Similar logic can be applied to the relationship between education externalities and unemployment. That is, while individuals residing in MSAs with greater college shares will have lower unemployment, the positive externality will be greater for the non-college worker who benefit from both spill over and substitution effects.

Other existing studies have found that education attainment appears to have a consistently downward effect on the regional unemployment rate. In fact, nearly all studies find that areas with greater shares of highly educated adults have lower unemployment rates. (Burridge and Gordon, 1981; Siegers, 1983; Simon 1988; Holzer, 1993). The existing literature offers several reasons why the share of college educated adults may reduce unemployment in these areas. First, better educated people may be more likely to be hired and less likely to be laid off as they possesses skills that may be relatively more difficult to replace. Second, regions with low levels of human capital may be caught up in a low-skilled poverty trap. Poor economic performance in these regions may encourage high skill labor to move out of the market, further lowering the average workforce productivity for these regions. (Taylor, 1996). Third, less educated people are likely to be uncompetitive and thus may face greater barriers for getting jobs in other regions. Moreover, these people are likely to face greater difficulties in finding a new house that they can afford, which also may prevent them from moving (Evans and McCormick, 1994). 
These studies, however, have focused only on the direct effect of educational attainment on unemployment. That is, those with higher levels of education are more likely to be employed compared to those with lower level of education. These studies, however, have overlooked the fact that college graduates may have a positive spillover effect on individuals' employment status, which we define as an indirect effect. If this hypothesis holds, we will find that people living in MSAs with higher shares of adult college graduates will have lower likelihoods of being unemployed, even after controlling for their own education levels.

This paper is also related to papers which find persistent divergence in the regional unemployment rate. Studies including Topel and Neumann (1991) and Partridge and Rickman (1997), find that the regional unemployment gap has been persistent in the U.S., and we do as well. Furthermore, our paper is the first to test whether the share of college graduates explains the long-term unemployment gap. We also examine whether the relationship between the MSA's education level and its long-term unemployment rate differs for college and non-college graduates.

\section{Data \& Method}

Data Our main data sources are the American Community Survey (ACS) and the Decennial Census. A limitation of two data sets is that they are not a panel, so they do not allow us to follow individual employment and unemployment spells. The benefit of the ACS and the Census is that they cover 1 percent (5 percent for the Census) of the U.S. population, which allows us to draw precise inferences from data sets that are carefully constructed to be representative.

We can, however, create a panel data set at the MSA level by aggregating the individual data. In our analysis, we implement both individual level cross-sectional and MSA level panel regressions. The individual sample is restricted to include those who report that they are in the labor force and are between ages 16 and 65. The individual level variables includes employment status, education level, race, tenure, sex and marital status. 
The MSA and the state level variables are collected from various different sources. The MSA unemployment rate is collected from the Bureau of Labor Statistics (BLS) from 1990 to 2011. However, the BLS does not separately provide unemployment rates of college graduates and non-college graduates. Thus, using the ACS and the Decennial Census we calculate the college and non-college unemployment rate for each MSA by dividing the total number of unemployed by the total number in the labor force ${ }^{4}$. From 1990 to 2011, the correlation between the MSA unemployment rate by BLS and our estimated unemployment rate is 80.0 percent. Our key explanatory variable is the proportion of adult college graduates in each MSA. For this variable, we calculate the percentage of those over 25 years old that received college education from the ACS and the Census. The control variables, including the percentage of those over 50 years old and the percentage of heads, owners, Whites and immigrants in MSAs, are also calculated using the ACS and the Census data.

Another MSA level control variable is the extent of industrial diversity. Existing studies ${ }^{5}$ suggest $^{-}$

\footnotetext{
${ }^{4}$ Note that the Decennial Census data is available in years 1990 and 2000 and the ACS is available annually from 2005. Thus, the years we use to calculate the college and non-college graduates' unemployment rate are 1990, 2000, 20052011. For the aggregate unemployment rate, we only present the regression results using the BLS unemployment rate. However, we find that our regression result do not change when we use the unemployment rate we calculated using the Census and the ACS.

${ }^{5}$ For example, Neumann and Topel (1991) argue that persistent difference in the regional unemployment rate is attributable to the differences in the covariance structure of sectoral demands for labor. If workers can easily switch between industries, than greater diversification of sectoral demands in a region could reduce its unemployment rate. More recently, Izreali and Murphy (2003) also find that industrial diversity reduces long-term unemployment rates. Their study uses the Herfindahl index, the sum of the squares of the shares of each industry within a state, as the proxy of diversity. However, the Herfindahl index may not be a good proxy of industrial diversity as the index does not capture the correlation in labor demand among industries. Herfindahl also does not adequately capture comparisons of regional with nation diversity because the index does not incorporate the relative industrial composition in a region to that of the whole nation. Both study uses state level data. Malizia and Ke (1993) is the only study we are aware of that uses MSA as its unit of analysis. In agreement with the two other studies, this study finds a negative association between unemployment rate and industrial diversity. Industry entropy is used as the proxy for diversity. However, Dissart (2003) criticizes this index as there is no economic justification of why region
} 
that areas with greater industrial diversity may have lower unemployment rates as workers could to switch to a firm in another industry when the job market condition in their own industry turns negative. This hypothesis only holds, however, when the workers are mobile across industries and do not endogeneously choose a location with better job opportunities. It is even possible that some workers may prefer a more specialized region if the region provides more jobs for their specific skills. Some firms may correspondently prefer to be located in these regions as they can acquire specific skilled labor at a lower cost. If so, the unemployment rate would be lower in areas with less industrial diversity. The positive relationship between unemployment rate and industrial diversity should be stronger for non-college graduates as these people in general are more likely to hold industry specific skills and face higher cost of migration.

In this paper we use two proxies of industrial diversity. First is national diversity, measured by the following equation:

$$
\mathrm{NA}=\sum_{i=1}^{N} \frac{\left(X_{i}-\overline{X_{l}}\right)^{2}}{\bar{X}_{i}}
$$

Where $X_{i}$ is the ith industry's share of employment in the region, $\bar{X}_{i}$ is the national average employment share in the ith industry and $\mathrm{N}$ is the number of industries in the region. This index estimates the how the regional employment percentages in each industry deviates from the national averages. The index is based on location quotients (Siegal, Johnson and Alwang, 1995) and increases as the region becomes more specialized. A local economy that is perfectly representative of the national economy would get an index value of zero.

The second proxy is a portfolio variance index. The index is borrowed from the finance theory and is currently the most commonly used (Dissart, 2003) measure of industrial diversification. The advantage of this index is that it incorporates the interrelationship between the industries. The index is measured by the following equation.

should have equal shares, given inherent differences in regions. 


$$
\mathrm{PV}=\sum_{i=1}^{N} W_{i}^{2} \operatorname{VAR}\left(X_{i}\right)+\sum_{i=1}^{N} \sum_{j=1, j \neq i}^{N} W_{i} W_{j} \operatorname{COV}\left(X_{i}, X_{j}\right)
$$

Where $W_{i}$ and $W_{j}$ is the share of employment in industry $\mathrm{i}$ and $\mathrm{j}$ in a region, $\operatorname{VAR}\left(X_{i}\right)$ is industry I's employment variance, and $\operatorname{COV}\left(X_{i}, X_{j}\right)$ is the employment covariance of industry $\mathrm{i}$ and $\mathrm{j} . \mathrm{N}$ again is the number of industries. Similar to the NA index, a higher PV index indicates a lower level of industrial diversity. To calculate the two proxies of industrial diversity, we use the employment data from the County Business Patterns (CBP) ${ }^{6}$. The variance and covariance matrix for the portfolio variance is estimated using annual data from 1990 through 2011.

State level variables includes maximum state wage tax rates, two political variables and January temperature. These variables are matched to each MSA. For MSAs which are located in multiple states, we allocate the weighted average of the state level variables using the share of MSA population residing in each state. The maximum state wage tax rates are obtained from the average state marginal income tax page from the National Bureau of Economic Research (NBER)'s TAXSIM project. ${ }^{7}$ The political variables are defined by both the proportion of the Senate and the House representatives. We designate blue states as those with two Democratic Senators, red states as those with two Republican Senators and purple states as those with one Senator from each party. Color equals zero for red states, one for purple states and two for blue states. We obtained the data from the U.S. Senate homepage ${ }^{8}$. Percent of Democrats are percent of votes the Democratic Party received in the most recent congressional election. The data is from the Office of the Clerk of the U.S. House Representatives ${ }^{9}$ Finally, January

\footnotetext{
${ }^{6}$ In 1997, the Standard Industrial Classification, which categorized industries into four digit codes, was replaced by the North American Industry Classification System (NAICS). NAICS also was revised in 2002, 2007 and 2012. In order to obtain a comparable diversity indices we match the two classification systems by the first two digits of the SIC codes. Both diversity indices are calculated at the two digit level.

${ }^{7}$ http://users.nber.org/ taxsim/state-rates/

${ }^{8}$ www.senate.gov

${ }^{9}$ clerk.house.gov/member_info/electioninfo/
} 
temperature data is from the National Climate Data Center (NCDC).

Table I presents the summary statistics. The average unemployment rate during $2005-2011$ is 8.2 percent. However, if we divide the unemployment rate into that of college and non-college graduates, we see that the college graduates unemployment rate is 6.5 percent lower. The standard deviation of unemployment rate is also lower for the college graduates. Cairo and Cajner (2013) provide one possible reason for this phenomenon. Their study finds that the more highly educated have much lower job-separation rates than less educated people. They suggest on-job training as the main factor that reduces job-separation. More specifically, firms provide more training to highly educated people, so they are less likely to fire these people (Becker, 1993). Those who receive more training are also less likely to quit their current job because of their company specific skills. (Williamson, 1981). As a result, both the unemployment rate and the employment volatility are lower for college graduates.

38.1 percent of the people in the sample hold a college degree. The average age is slightly less than 40. Over 63.6 percent of the sample are non-Hispanic White. Hispanic accounts for 17.1 percent followed by Black (13.3 percent). 18.9 percent of people in the sample are immigrants. Half of the sample are heads while owners account for 65.9 percent. Since the individual sample only includes those in the labor force, the percent of female is lower than that of the male. Over 50 percent of the sample are married and 33 percent are single.

The MSA level variables are slightly different from the individual level variables as they are calculated by including both the people in and out of the labor force. For most variables, the difference between labor force and MSA descriptive statistics is small. One exception is household head share, which is $\mathbf{3 7 . 2}$ percent in the MSA data but is 50 percent in the labor force data. Among the state level variables, the mean value of maximum state wage tax is 5.3 percent. In our analysis, 49.7 percent of people live in blue states, while 22.1 percent reside in purple states. The Democratic Party on average received 47.3 percent of votes in the congressional elections during 2005-2011. 


\section{Method}

The main purpose of this paper is to identify whether college graduates produce spillover benefits on unemployment at both the individual and the MSA level. To examine this relationship, the first regression model uses the individual level unemployment data from the ACS from 2005 to 2011. Model (1) estimates the following equation:

$\mathrm{P}\left(\mathrm{UE}_{\mathrm{it}}\right)=\alpha \operatorname{Coll}_{\mathrm{it}}+\beta \% \operatorname{Coll}_{\mathrm{mt}}+\gamma \% \operatorname{Coll}_{\mathrm{mt}} * \mathrm{NonColl}_{\mathrm{it}}+\delta \mathrm{X}_{\mathrm{it}}+\theta \mathrm{Y}_{\mathrm{mt}}+\mu \mathrm{Z}_{\mathrm{st}}+\tau_{\mathrm{s}}+\varphi_{\mathrm{t}}+\varepsilon_{\mathrm{it}}$

, where $\mathrm{P}\left(\mathrm{UE}_{\mathrm{it}}\right)$ is the probability that individual $\mathrm{i}$ is unemployed at time $t$, and $\mathrm{UE}_{\mathrm{it}}$ equals 1 if the individual is unemployed ${ }^{10}$. Coll ${ }_{\text {it }}$ controls for individual's education level and equals 1 if the person has a college degree. $\%$ Coll $_{m t}$ indicates the adult share of college graduates in the MSA that the individual is residing at time $t$. If the individual is affected not only by their own education level but also by the education level of those living within the same MSA, than $\beta$ should have a significant value. We also include the interaction term of $\% \mathrm{Coll}_{\mathrm{mt}} * \mathrm{NonColl}_{\mathrm{it}}$ to identify whether $\%$ Coll $_{m t}$ has a different effect on the individual's unemployment status depending on the education level. When the interaction term is included, $\beta$ measures how $\%$ Coll $_{m t}$ affects unemployment of college graduates, while $\gamma$ measures how $\% \mathrm{Coll}_{\mathrm{mt}}$ affects the unemployment of non college graduates.

The regression also controls for various individual control variables $\mathrm{X}_{\mathrm{it}}$, including age, race, immigrant and marital status, and whether the individual is a head or an owner. $Y_{m t}$ indicates MSA control variables such as the two measures of industrial diversity, headship rate, population-based ownership rate ${ }^{11}$ and the share of the $50+$ population, Whites and

\footnotetext{
${ }^{10}$ In the current version of this paper, we use the OLS to estimate model (1). When the model is finalized, we will use either the logit or the probit model than calculate the marginal effect. Studies including Angrist and Pischke (2009) suggest that the difference between marginal effect calculated from the linear probability model and the logit or the probit model is minor.

${ }^{11}$ Unlike the conventional homeownership rate which is measured by dividing owners by heads, the population-
} 
immigrants. $Z_{\text {st }}$ indicates state control variables which are state's maximum wage tax rate, the two political variables mentioned in the data section, and the January temperature. We also add state $\left(\tau_{\mathrm{s}}\right)$ and year $\left(\varphi_{\mathrm{t}}\right)$ fixed effects. Finally, $\varepsilon_{\mathrm{it}}$ is the random error term, which is assumed to be normally distributed.

The next model aggregates individual employment status, and uses the average MSA unemployment rate as the dependent variable. The model's purpose is to check whether the results from model (1) still hold at the MSA level. Model (2) is:

$\mathrm{UE}_{\mathrm{mt}}=\alpha \% \operatorname{Coll}_{\mathrm{mt}}+\beta \mathrm{Y}_{\mathrm{mt}}+\gamma \mathrm{Z}_{\mathrm{st}}+\tau_{\mathrm{s}}+\varphi_{\mathrm{t}}+\varepsilon_{\mathrm{it}}$

Where $\mathrm{UE}_{\mathrm{mt}}$ is the unemployment rate of each MSA at time t. We further calculate the unemployment rate of college graduates and non-college graduates using the ACS. Model (2) also estimates the same regression using the unemployment rate of college graduates and the unemployment rate of non-college graduates as dependent variables. The key control variable is $\% \mathrm{Coll}_{\mathrm{mt}}$. If MSAs with higher share of adult college graduates have lower unemployment rate only because the college graduates unemployment rate is lower, than $\alpha$ will be negative only in the regression where the dependent variable is the total unemployment rate. In the regressions using college or non-college unemployment rate, $\alpha$ will be zero. On the other hand, if indirect effects exists, then $\alpha$ will be significantly negative for all three measures of unemployment. Again, $\mathrm{Y}_{\mathrm{mt}}$ indicates $\mathrm{MSA}$ control variables and $\mathrm{Z}_{\text {st }}$ indicates state control variables. The state and the year fixed effect are also included in the equation.

The third model tests whether the share of college graduates has a long term effect on the MSA unemployment rate. In order to examine this relationship, we first regress the MSA unemployment rate on both MSA and year fixed effects from 1990 to 2011, and obtain fixed effect coefficients for every MSA. We use these coefficients as the dependent variable and

based ownership rate divides owners with the total number of population. The two different measures of homeownership do not lead to noticeable differences in the results. 
estimate the following equation:

UE_Fixed $_{\mathrm{mt}}=\alpha \% \operatorname{Coll}_{\mathrm{mt}-10}+\beta \mathrm{Y}_{\mathrm{mt}-10}+\gamma \mathrm{Z}_{\mathrm{st}-1}+\varepsilon_{\mathrm{it}} \quad(\mathrm{M} 3)$

, where UE_Fixed $\mathrm{mt}_{\mathrm{mt}}$ are the MSA fixed effect coefficients. We calculated three sets of MSA fixed effects coefficients: one using the BLS unemployment rate, one using the Census/ACS college unemployment rate, and one using the Census/ACS non-college unemployment rate. We then perform separate regressions for each type of unemployment. The right hand side variables are similar to those used in model (2), but are lagged in order to mitigate simultaneity. For variables obtained from the Census, we use 1980 data; for variable obtained from other sources, we use 1989 data. The cross sectional nature of the data prevent us from using time fixed-effects; the paucity of degrees of freedom prevent us from using state level fixed effects.

The final two models explore why unemployment is more persistent in some MSAs relative to others. While higher college share may be correlated with lower levels of unemployment in the short run, if firms and households move from high- to low-unemployment MSAs, unemployment rates should eventually converge. Long-run gaps in unemployment suggest the existence of factors that inhibit firms and households from moving.

First, if firms are more productive in MSAs with more educated people (Morretti 2004a), then firms will prefer to locate in these areas. These MSAs are also likely to have lower levels of unemployment, because more productive firms have reason to hire more workers. However, if the presence of college graduates increases wages, the cost of production offsets the productivity benefits in areas with greater shares of college graduates. Thus, in equilibrium, firms become indifferent between MSAs with high or low share of college graduates. Model (4) tests this hypothesis.

$\mathrm{W}_{\mathrm{mt}}=\alpha \% \operatorname{Coll}_{\mathrm{mt}}+\beta \mathrm{Y}_{\mathrm{mt}}+\gamma \mathrm{Z}_{\mathrm{st}}+\tau_{\mathrm{s}}+\varphi_{\mathrm{t}}+\varepsilon_{\mathrm{it}}$ 
, where $\mathrm{W}_{\mathrm{mt}}$ is the log value of the average wage in each MSA from the ACS 2005-2011. The average wage is also calculated separately for college and non-college graduates. All the explanatory variables are identical to those in model (2).

Meanwhile, the final model offers a possible explanation why the households may not move to a MSA with lower a lower unemployment rate. While households may desire to move to areas that offer more jobs, they may not be able to do so as these areas have higher house prices. The high house prices may eliminate incentives to move to areas with lower unemployment. This hypothesis is tested by the following model:

$\mathrm{HP}_{\mathrm{mt}}=\alpha \%$ Coll $_{\mathrm{mt}}+\beta \mathrm{Y}_{\mathrm{mt}}+\gamma \mathrm{Z}_{\mathrm{st}}+\tau_{\mathrm{s}}+\varphi_{\mathrm{t}}+\varepsilon_{\mathrm{it}}$

, where $\mathrm{HP}_{\mathrm{mt}}$ is the log value of the average American Community Survey house price in each MSA from 2005 to 2011. The model uses the same explanatory variables as models (2) and (4). When estimated, the individual level model is weighted by the person weight provided by the ACS and the four MSA models are weighted by the MSA population.

\section{Results}

Table II present the result of model (1), which estimates an individual's likelihood of being unemployed using the ACS data from 2005 to 2011. The result in the first column shows that college graduates are less likely to be unemployed than those who did not receive a college degree. Our regression results also show that the likelihood of being unemployed is lower for those residing in MSAs with more college graduates. The negative coefficient of the interaction term shows that proportion of college graduates in MSAs further lowers the unemployment propensity of those without a college degree. This suggests that the indirect effect of higher education is greater for the less educated group. The result remains unchanged after controlling for the individual level variables (column (2)) and MSA level variables (columns (3) \& (4)).

The probability of being unemployed convexly decreases with age. Blacks, Asians and Latinos 
are more likely to be unemployed compared to Whites. Immigrants within our sample have a lower likelihood of being unemployed. As expected, heads and those who are married are less likely to be unemployed. Homeowners are also less likely to be unemployed but this may be the result of individual level unobserved variables: those with the organizational skills to become homeowners may also fare better in the job market. Women have a lower likelihood of being unemployed than men, but women are also more likely to be out of the labor force.

The level of industrial diversity, measured by the portfolio variance index, does not show any statistical significance. The diversity level as measured by the national average index ${ }^{12}$, however, has a negative coefficient. This suggests that individuals are less likely to be unemployed if they reside in MSAs that focus on a specific industry, in agreement with our hypothesis.

In contrast to the individual owner dummy, the proportion of owners in MSAs increases the likelihood of individual level unemployment. The negative sign of the percent of owners is in line with the Oswald's (1999) hypothesis, which suggests that homeownership increases regional unemployment due to the presence of a lock-in effect. More specifically, this theory suggests that unemployed homeowners are less likely to move to a better job market than unemployed renters, thus increasing the aggregate unemployment in areas with greater shares of homeowners. Living in an MSA with a higher proportion of elderly and immigrants increases an individual's likelihood of being unemployed. On the other hand, the percentage of Whites in an MSA has a negative coefficient.

Since we include state fixed effect in all four regressions, the state level variables should be interpreted as changes over time. For example, the result shows that changes in wage taxes do not have any relationship with an individual's employment status. Interestingly, the political variables have different associations with the propensity for unemployment, depending on whether the indices are measured at the Senate or the House level. The presence of more Democratic Senators lowers the likelihood of individual unemployment while the opposite holds

\footnotetext{
${ }^{12}$ See equations (1) \& (2).
} 
for an increase of Democratic House representatives. Finally, the likelihood of being unemployed increases when tested against zero at the 99 percent level of confidence when the January temperature increases, but the magnitude of the coefficient is close to zero.

Table III presents the MSA level analysis from 2005-2011 to check if this analysis confirms the individual level analysis. The dependent variable is the MSA unemployment rate in columns (1)(3), the MSA unemployment rate of college graduates in columns (4)-(6) and the MSA unemployment rate of non-college graduates in columns (7)-(9) ${ }^{13}$. The results in columns (1)-(3) show that the aggregate unemployment rate is lower in MSAs with larger shares of college graduates. If there are no spillover effects, this could be solely due to the fact that college graduates have, in general, lower unemployment rates than high school graduates. If there are no spillovers, the coefficient for the percentage of college graduates in columns (4)-(6) and (7)(9) should be zero. The results in these columns show that this is not the case. The coefficients in both columns are negative and statistically significant. Furthermore, the absolute size of the percentage of college graduate coefficients are larger in regressions (7)-(9) compared to regressions (4)-(6) This is in line with the results in Table II which shows that the indirect effect of education is greater for the non-college graduates.

As for the other control variables, we find that portfolio variance index has no statistical significance while the national average index shows negative association with all three measures of unemployment. In other words, unemployment is lower in less diversified MSA. The size of the coefficient is greater for the less educated, consistent with our hypothesis that suggests the lower skilled are more likely to find jobs in specialized areas. The headship rate shows a negative coefficient only in the regressions that use the ACS unemployment data. In contrast to the individual level analysis, the percentage of owners shows no relationship with

\footnotetext{
${ }^{13}$ Note that we use BLS unemployment rate for the total MSA unemployment rate. In most variables, result do not show noticeable difference when we use the unemployment rate estimate that we calculate using the ACS. The only difference is shown in the statistical significance of the headship variable and the percent of older population. When using the ACS data we see that percent of heads are negatively associated with the MSA unemployment rate.
} 
the aggregate unemployment rate. This may be due to the different signs of ownership coefficients between the individual variable and the MSA variable in Table II. More specifically, since homeowners are more likely to be employed than renters, having more homeowners lowers the MSA unemployment rate. On the other hand, homeowners may also be locked-in, which increases the MSA unemployment rate, once the individual effect is controlled for. These two effects may have offset each other in the MSA level regression. While MSAs with higher percentages of Whites have lower unemployment rates, the college unemployment rate is less affected by the percentage of Whites than the non-college unemployment rate. Meanwhile, the proportion of older population increases the unemployment rate of non-college graduates more than the unemployment rate of college graduates. The percent of immigrants is positively associated with the college unemployment rate but not with the non-college unemployment rate. The results of the state level variables are similar to the results in table II. The coefficient on wage tax is not significantly different from zero at any customary level, the coefficients on the two political variables are mostly significant and show different signs, and January temperature has a positive coefficient that is small in size.

Next, we look at the long-term MSA unemployment rates. Tables IV and V provide results which show that MSA unemployment rates are persistent over time. Using these results, we investigate factors that explain the long -run divergence in the MSA unemployment rate using Model (4), and present the results in table VI. First, table IV shows that MSA and year fixed effects can explain 84 percent of MSA unemployment variance from 1990 to 2011 . The MSA fixed effects explain 60 percent of the variance and the year fixed effects explain the remaining 24 percent. This indicates that unemployment in each MSA is largely fixed by region and fluctuates with the national trend. Figure 1 shows how strongly time and MSA fixed effects predict unemployment, as a plot of actual vs. fitted unemployment clusters closely to the 45 degree line.

The next table presents the R-squareds of regressions of four different measures of unemployment rates on MSA and year fixed effects. The years of estimation are 1990, 2000, and 
2005-2011, years for which the Census or the ACS data are available. The four regressions are: BLS all workers, Census/ACS all workers, Census/ACS college graduates, and Census/ACS noncollege graduates. The R-squared is higher for the MSA unemployment rate from the BLS compared to the MSA unemployment rate we calculated using the Census/ACS data. Still the Rsquared is over 76 percent for the ACS unemployment rate. The R-squared for the non-college unemployment rate is higher than the college unemployment rate. This may be due to the fact that better educated people have a greater chance of moving to a location with a better job opportunity as they face relatively lower migration cost (Ganong \& Shoag, 2013).

Table VI presents the results of the regression of the MSA fixed effect coefficients on mostly the same independent variables used in table III. Since we did not include the state fixed effects in the regression, we replace the color variable with blue and the purple state dummy ${ }^{14}$. All independent variables are lagged to mitigate endogeneity. The results show that the percentage of college graduates in 1980 has a negative association with total, college and non-college MSA unemployment fixed effect coefficients. This suggests that the share of college graduates has a long-term impact on MSA unemployment. Again, the size of the coefficient is greater for the non-college graduates indicating that college education has both spill over and substitution effect on non-college unemployment rate.

Compared to the previous two results, some differences are observed in the sign and the significance of other control variables. First, the percentage of heads in the 1980s has no relationship with the total and the non-college unemployment fixed effects, while the variable has a positive relationship with the college unemployment fixed effects. The past share of homeowners also has a positive impact on the all three unemployment fixed effects supporting the Oswald hypothesis. In contrast to the result in Table IV, the share of age over 50 has a negative relationship with the total unemployment fixed effects, while the relationship with the other two unemployment fixed effects is insignificant. Share of Whites have negative impact

\footnotetext{
${ }^{14}$ For the regressions with the state fixed effects, it is difficult to explain the dummy variables for Blue and Purple states since the interpretation the variables should be interpreted as changes over time.
} 
only on the non-college unemployment fixed effects. The past share of immigrants lowers the long-term unemployment rate in all three measurements. Wage tax, which did not show any association with any of the unemployment rates in the previous results, seems have a positive long-term effect on all three unemployment rates. MSAs in lagged blue or purple states have higher long term unemployment rate compare to the red states. The lagged share of Democrats also has a positive association with the total unemployment fixed effect while no relationship with shown with the other two fixed effects. Finally, the results show that the January temperature does not have any statistical relationship with the long term MSA unemployment rate.

While the signs and the significance of the some control variables differs in table VI compared to those in table IV, it is noteworthy that the share of college graduates remains negative and significant. This suggests that the share of college graduates are not only positively associated with the current level of unemployment but also reduces the long-term unemployment rate.

The final two tables examine two possible reasons that explain the existing unemployment rate gap among MSAs. Table VII shows that even after including the control variables, the average wage is higher in MSAs with greater shares of college graduates. This is not only due to the fact that college graduates have higher wages (direct effect) but also because the average wage of both college and non-college graduates are higher in MSAs with greater shares of college graduates (indirect effect). The results are in line with Morretti (2004b). If higher shares of college graduates is associated with higher productivity, firms may choose to move to these locations. This will lower the unemployment rate of the MSAs with greater shares of college graduates, which will eventually lead to an unemployment rate convergence. However, higher average wage in MSAs with higher proportion of college graduates offsets the productivity benefits, encouraging firms to remain in place.

Finally, table VIII shows that the average MSA house values are higher in areas with greater shares of college graduates. This suggests that while households would prefer to move to an 
area with lower unemployment rates, higher house prices in these locations may hamper them from moving. The barrier will be greater for less educated households, who on average have fewer capital resources. Thus, less well education households may be more likely to remain in place, resulting in a persistent divergence in MSA unemployment rates.

\section{Conclusion}

Following the 2007 housing market crisis, the national unemployment peaked at 10 percent in October 2009, causing a burden on the US economy while aggravating the lives of many households. Although almost all MSAs experienced an increase in the unemployment rate, there was and continues to be great dispersion in the level of the unemployment rate across MSAs. For example, in 2011, the unemployment rate of MSAs ranged from Bismarck, North Dakota's low of 3.8 percent to Dutchess County, New York's high of 29.9 percent. Among many factors, we find that education is critical to explaining the persistent divergence in the MSA unemployment rates. MSAs with greater shares of college graduates have lower unemployment rates. Also, the size of this positive externality is greater for the less educated, who benefit from both spillover and substitution effects. Those who received college educations also benefit from spillover effects, but the competition among themselves may reduce the benefit.

The relationship between employment and the share of college educated adults holds whether we test it at the individual level or MSA level, and also remains in place in the long run. We find that the differences in house prices and wages are the two possible barriers that hamper households and firms to migrate, preventing MSA unemployment rates from converging. In equilibrium, firms do not move to cities with higher overall levels of education, as they need to pay higher wages whose costs just match the benefits of productivity gains. The workers are also indifferent among cities, as more productive cities have the higher house prices, that at least partially offsets the higher wages available in areas with higher shares of college graduates. In short, after taking account differences in living costs, real wages equalize across regions, even in the presence of differences in unemployment. 


\section{References}

Acemoglu, D., \& Angrist, J. (2000). How Large are Human Capital Externalities? Evidence from Compulsory Schooling Laws (Vol. 15). Cambridge, MA: MIT Press.

Angrist, J., \& Pischke, J.-S. (2009). Mostly Harmless Econometrics. Princeton University Press.

Becker, G. (1993). Human Capital: Theoretical and Empirical Analysis, with Special Reference to Education (3rd ed.). Chicago and London: University of Chicago Press.

Burridge, P., \& Gordon, I. (1981). Unemployment in the British Metropolitan Labour Area. Oxford Economic Papers, 33, 274-297.

Cairo, I., \& Cajner, T. (2013). Human Capital and Unemployment Dynamics: Why More Educated Workers Enjoy Greater Employment Stability. Working Paper.

Ciccone, A., \& Peri, G. (2006). Identifying Human-Capital Externalities: Theory with Applications. The Review of Economic Studies, 73(2), 381-412.

Dissart, J. C. (2003). Regional Economic Diversity and Regional Economic Stability. International Regional Science Review, 26(3), 423-446.

Elhorst, J. P. (2003). The Mystery of Regional Unemployment Differentials: Theoretical and Empirical Explanations. Journal of Economic Surveys, 17(5), 709-748.

Evans, P., \& McCormick, B. (1994). The New Pattern of Regional Unemployment: Causes and Policy Significance. Economic Journal, 104, 633-647.

Ganong, P., \& Shoag, D. (2013). Why Has Regional Income Convergence in the U.S. Declined? Working Paper.

Holzer, H. J. (1991). Employment, Unemployment and Demand Shifts in Local Labour Markets. Review of Economics and Statistics, 73, 25-32.

Malizia, E. E., \& Ke, S. (1993). The Influence of Economic Diversity on Unemployment and Stabliity. Journal of Regional Studies, 33, 221-235.

Moretti, E. (2004b). Estimating the Social Return to Higher Education: Evidence from Longitudinal and Repeated Cross-Sectional Data. Journal of Econometrics, 121, 175-212.

Moretti, E. (2004a). Workers' Education, Spillovers, and Productivity; Evidence from Plant-Level Production Functions. American Economic Review, 94(3), 656-690.

Neumann, G. R., \& Topel, R. H. (1991). Employment Risk, Diversification, and Unemployment. 
Quarterly Journal of Economics, 106, 1341-1365.

Oswald, A. J. (1999). The Housing Market and Europe's Unemployment: A Non-technical Paper. Mimeo University of Warwick.

Partridge, M. D., \& Rickman, D. S. (1997). The Dispersion of US State Unemployment Rates: The Role of Market and Non-market Equilibrium Factors. Regional Studies, 31, 593-606.

Rauch, J. E. (1993). Productivity Gains from Geographic Concentration of Human Capital: Evidence from the Cities. Journal of Urban Economics, 34(1), 380-400.

Roback, J. (1982). Wages, Rents and the Quality of Life. Journal of Political Economy, 90(6), 12571278.

Roback, J. (1988). Wages, Rents and Amenities: Difference among Workers and Regions. Economic Inquiry, 26(1), 23-41.

Siegel, P. B., Johnson, T. G., \& Alwang, J. (1995). Regional Economic Diversity and Diversification. Growth and Change, 26(2), 261-284.

Siegers, J. J. (1983). An Economic-Demographic Ten-Equation Model. De Economist, 131, 400-443.

Simon, C. J. (1988). Frictional Unemployment and the Role of Industrial Diversity. Quarterly Journal of Economics, 103, 715-728.

Taylor, J. (1996). Regional Problems and Policies: A European Perspective. Australasian Journal of Regional Studies, 2, 103-131.

Williamson, O. E. (1981). Economics of Organization: The Transaction Cost Approach. American Journal of Sociology, 87(3), 548-577. 


\section{Tables \& Figures}

[Table I] Summary Statistics 2005-2011

\begin{tabular}{|c|c|c|}
\hline Variable & Mean & Std. Dev. \\
\hline \multicolumn{3}{|l|}{ Individual Level } \\
\hline Unemployed & 0.082 & 0.275 \\
\hline Unemployed-College & 0.043 & 0.203 \\
\hline Unemployed-Non College & 0.108 & 0.310 \\
\hline College & 0.398 & 0.489 \\
\hline Age & 39.414 & 12.641 \\
\hline White & 0.636 & 0.481 \\
\hline Black & 0.133 & 0.339 \\
\hline Asian & 0.061 & 0.239 \\
\hline Hispanic & 0.171 & 0.377 \\
\hline Immigrant & 0.189 & 0.392 \\
\hline Head & 0.500 & 0.500 \\
\hline Own & 0.659 & 0.474 \\
\hline Female & 0.469 & 0.499 \\
\hline Married & 0.518 & 0.500 \\
\hline Divorced/Separated & 0.137 & 0.343 \\
\hline Widowed & 0.013 & 0.113 \\
\hline Single & 0.333 & 0.471 \\
\hline \multicolumn{3}{|l|}{ MSA Level } \\
\hline$\%$ of College Graduates & 0.3809 & 0.0706 \\
\hline Diversity: Portfolio Variance (PV) & 26.212 & 0.612 \\
\hline Diversity: National Average (NA) & 0.476 & 1.107 \\
\hline$\%$ of Age $50+$ & 0.283 & 0.040 \\
\hline$\%$ of Heads & 0.372 & 0.030 \\
\hline$\%$ of Owners & 0.655 & 0.085 \\
\hline$\%$ of Whites & 0.711 & 0.123 \\
\hline$\%$ of Immigrants & 0.160 & 0.106 \\
\hline \multicolumn{3}{|l|}{ State Level } \\
\hline Wage Tax & 0.053 & 0.034 \\
\hline Blue & 0.493 & 0.500 \\
\hline Purple & 0.221 & 0.415 \\
\hline$\%$ of Democrats (House) & 0.473 & 0.096 \\
\hline January Temperature & 35.753 & 11.941 \\
\hline Observation & \multicolumn{2}{|c|}{7300000} \\
\hline
\end{tabular}


[Table II] Individual unemployment 2005-2011

\begin{tabular}{|c|c|c|c|c|}
\hline VARIABLES & $\begin{array}{c}(1) \\
\text { Basic }\end{array}$ & $\begin{array}{c}\text { (2) } \\
\text { Individual } \\
\text { Control } \\
\end{array}$ & $\begin{array}{c}\text { (3) } \\
\text { MSA Control I }\end{array}$ & $\begin{array}{c}\text { (4) } \\
\text { MSA Control II }\end{array}$ \\
\hline College Graduates & $\begin{array}{c}-0.0781^{* * *} \\
(0.0060)\end{array}$ & $\begin{array}{c}-0.0600 * * * \\
(0.0052)\end{array}$ & $\begin{array}{c}-0.0645^{* * *} \\
(0.0058)\end{array}$ & $\begin{array}{c}-0.0648^{* * *} \\
(0.0058)\end{array}$ \\
\hline$\%$ College Graduate & $\begin{array}{c}-0.0322^{* * *} \\
(0.0093)\end{array}$ & $\begin{array}{c}-0.0372 * * * \\
(0.0098)\end{array}$ & $\begin{array}{c}-0.0367^{* * *} \\
(0.0136)\end{array}$ & $\begin{array}{c}-0.0420 * * * \\
(0.0137)\end{array}$ \\
\hline Non-College*\% College & $\begin{array}{c}-0.0352^{* *} \\
(0.0148)\end{array}$ & $\begin{array}{c}-0.0544^{* * *} \\
(0.0136)\end{array}$ & $\begin{array}{c}-0.0674 * * * \\
(0.0150)\end{array}$ & $\begin{array}{c}-0.0681^{* * *} \\
(0.0149)\end{array}$ \\
\hline Age & & $\begin{array}{c}-0.0091^{* * *} \\
(0.0003)\end{array}$ & $\begin{array}{c}-0.0085^{* * *} \\
(0.0003)\end{array}$ & $\begin{array}{c}-0.0085 * * * \\
(0.0003)\end{array}$ \\
\hline $\mathrm{Age}^{2}$ & & $\begin{array}{l}0.0001 * * * \\
(3.14 \mathrm{e}-06)\end{array}$ & $\begin{array}{c}9.45 e-05^{* * *} \\
(3.37 e-06)\end{array}$ & $\begin{array}{c}9.45 \mathrm{e}-05^{* * *} \\
(3.37 \mathrm{e}-06)\end{array}$ \\
\hline Black & & $\begin{array}{c}0.0612^{* * *} \\
(0.0028)\end{array}$ & $\begin{array}{c}0.0627^{* * *} \\
(0.0028)\end{array}$ & $\begin{array}{c}0.0627^{* * *} \\
(0.0028)\end{array}$ \\
\hline Asian & & $\begin{array}{c}0.0157^{* * *} \\
(0.0015)\end{array}$ & $\begin{array}{c}0.0122^{* * *} \\
(0.0014)\end{array}$ & $\begin{array}{c}0.0123 * * * \\
(0.0014)\end{array}$ \\
\hline Hispanic & & $\begin{array}{c}0.0127^{* * *} \\
(0.0020)\end{array}$ & $\begin{array}{c}0.0140 * * * \\
(0.0018)\end{array}$ & $\begin{array}{c}0.0140 * * * \\
(0.0018)\end{array}$ \\
\hline Immigrant & & $\begin{array}{c}-0.0129 * * * \\
(0.0015)\end{array}$ & $\begin{array}{c}-0.0109 * * * \\
(0.0013)\end{array}$ & $\begin{array}{c}-0.0109 * * * \\
(0.0013)\end{array}$ \\
\hline Head & & $\begin{array}{c}-0.0328 * * * \\
(0.0008)\end{array}$ & $\begin{array}{c}-0.0352^{* * *} \\
(0.0011)\end{array}$ & $\begin{array}{c}-0.0352^{* * *} \\
(0.0011)\end{array}$ \\
\hline Own & & $\begin{array}{c}-0.0173^{* * *} \\
(0.0008)\end{array}$ & $\begin{array}{c}-0.0197^{* * *} \\
(0.0012)\end{array}$ & $\begin{array}{c}-0.0197^{* * *} \\
(0.0012)\end{array}$ \\
\hline Female & & $\begin{array}{c}-0.0099 * * * \\
(0.0009)\end{array}$ & $\begin{array}{c}-0.0113^{* * *} \\
(0.0011)\end{array}$ & $\begin{array}{c}-0.0113^{* * *} \\
(0.0011)\end{array}$ \\
\hline Divorced/Separated & & $\begin{array}{c}0.0343^{* * *} \\
(0.0009)\end{array}$ & $\begin{array}{c}0.0381 * * * \\
(0.0008)\end{array}$ & $\begin{array}{c}0.0381^{* * *} \\
(0.0008)\end{array}$ \\
\hline Widowed & & $\begin{array}{c}0.0296 * * * \\
(0.0017)\end{array}$ & $\begin{array}{c}0.0350 * * * \\
(0.0016)\end{array}$ & $\begin{array}{c}0.0350 * * * \\
(0.0016)\end{array}$ \\
\hline Single & & $\begin{array}{c}0.0337^{* * *} \\
(0.0011)\end{array}$ & $\begin{array}{c}0.0375^{* * *} \\
(0.0011)\end{array}$ & $\begin{array}{c}0.0375^{* * *} \\
(0.0011)\end{array}$ \\
\hline Portfolio Diversity & & & $\begin{array}{l}-0.0003 \\
(0.0006)\end{array}$ & \\
\hline National Diversity & & & & $\begin{array}{c}-0.0014^{* * *} \\
(0.0005)\end{array}$ \\
\hline$\%$ Heads & & & $\begin{array}{l}-0.0583 \\
(0.0578)\end{array}$ & $\begin{array}{l}-0.0449 \\
(0.0573)\end{array}$ \\
\hline$\%$ Owners & & & $\begin{array}{l}0.0375 * \\
(0.0209)\end{array}$ & $\begin{array}{c}0.0415^{* *} \\
(0.0208)\end{array}$ \\
\hline$\%$ Age $50+$ & & & $0.108 * * *$ & $0.104^{* * *}$ \\
\hline
\end{tabular}




\begin{tabular}{|c|c|c|c|c|}
\hline & & & $(0.0352)$ & $(0.0343)$ \\
\hline \multirow{2}{*}{$\%$ Whites } & & & $-0.0287 * * *$ & $-0.0261 * * *$ \\
\hline & & & $(0.0090)$ & $(0.0089)$ \\
\hline \multirow[t]{2}{*}{$\%$ Immigrants } & & & $0.0473^{* * *}$ & $0.0496 * * *$ \\
\hline & & & $(0.0180)$ & (0.0169) \\
\hline \multirow[t]{2}{*}{ Wage Tax } & & & 0.0069 & 0.0094 \\
\hline & & & $(0.135)$ & $(0.134)$ \\
\hline \multirow[t]{2}{*}{ Color } & & & $-0.0025^{*}$ & $-0.0025^{*}$ \\
\hline & & & $(0.0013)$ & $(0.0013)$ \\
\hline \multirow[t]{2}{*}{$\%$ Democrats } & & & 0.0067 & 0.0069 \\
\hline & & & $(0.00865)$ & $(0.00865)$ \\
\hline \multirow[t]{2}{*}{ January Temperature } & & & $0.0007^{* * *}$ & $0.0007^{* * *}$ \\
\hline & & & $(0.0002)$ & $(0.0002)$ \\
\hline \multirow[t]{2}{*}{ Constant } & $0.115^{* * *}$ & $0.304 * * *$ & $0.252 * * *$ & $0.238 * * *$ \\
\hline & $(0.0051)$ & $(0.0075)$ & $(0.0315)$ & $(0.0256)$ \\
\hline Year FE & $Y$ & $Y$ & $Y$ & $Y$ \\
\hline State FE & $\mathrm{Y}$ & $Y$ & $Y$ & $Y$ \\
\hline Observations & $7,279,294$ & $7,279,294$ & $4,195,125$ & $4,195,125$ \\
\hline R-squared & 0.021 & 0.048 & 0.052 & 0.052 \\
\hline
\end{tabular}


[Table II] MSA level unemployment 2005-2011

\begin{tabular}{|c|c|c|c|c|c|c|c|c|c|}
\hline \multirow[b]{2}{*}{ VARIABLES } & \multicolumn{3}{|c|}{ Total Unemployment } & \multicolumn{3}{|c|}{ College Unemployment } & \multicolumn{3}{|c|}{ Non-College Unemployment } \\
\hline & (1) & $(2)$ & (3) & (4) & (5) & (6) & (7) & (8) & (9) \\
\hline$\%$ College Graduate & $\begin{array}{c}-0.111^{* * *} \\
(0.0082)\end{array}$ & $\begin{array}{c}-0.155^{* * *} \\
(0.0125)\end{array}$ & $\begin{array}{c}-0.159 * * * \\
(0.0128)\end{array}$ & $\begin{array}{c}-0.0181^{* * *} \\
(0.0043)\end{array}$ & $\begin{array}{c}-0.0142 * * \\
(0.0067)\end{array}$ & $\begin{array}{c}-0.0171 * * \\
(0.0068)\end{array}$ & $\begin{array}{c}-0.0728 * * * \\
(0.0085)\end{array}$ & $\begin{array}{c}-0.0784 * * * \\
(0.0116)\end{array}$ & $\begin{array}{c}-0.0854 * * * \\
(0.0117)\end{array}$ \\
\hline Portfolio Diversity & & $\begin{array}{c}0.0004 \\
(0.0007)\end{array}$ & & & $\begin{array}{l}-0.0005 \\
(0.0004)\end{array}$ & & & $\begin{array}{l}-0.0002 \\
(0.0009)\end{array}$ & \\
\hline Nation Diversity & & & $\begin{array}{c}-0.0010 * * * \\
(0.0004)\end{array}$ & & & $\begin{array}{c}-0.0007 * * * \\
(0.0002)\end{array}$ & & & $\begin{array}{c}-0.0018 * * * \\
(0.0004)\end{array}$ \\
\hline$\%$ Heads & & $\begin{array}{c}0.0464 \\
(0.0435)\end{array}$ & $\begin{array}{c}0.0561 \\
(0.0436)\end{array}$ & & $\begin{array}{c}-0.0842 * * * \\
(0.0288)\end{array}$ & $\begin{array}{c}-0.0769 * * * \\
(0.0291)\end{array}$ & & $\begin{array}{c}-0.146 * * * \\
(0.0520)\end{array}$ & $\begin{array}{l}-0.129 * * \\
(0.0521)\end{array}$ \\
\hline$\%$ Owners & & $\begin{array}{l}9.33 e-05 \\
(0.0168)\end{array}$ & $\begin{array}{c}0.0029 \\
(0.0171)\end{array}$ & & $\begin{array}{c}0.0081 \\
(0.0098)\end{array}$ & $\begin{array}{c}0.0100 \\
(0.0098)\end{array}$ & & $\begin{array}{l}-0.0263 \\
(0.0208)\end{array}$ & $\begin{array}{l}-0.0213 \\
(0.0210)\end{array}$ \\
\hline$\%$ Age $50+$ & & $\begin{array}{c}0.0074 \\
(0.0268)\end{array}$ & $\begin{array}{c}0.0043 \\
(0.0268)\end{array}$ & & $\begin{array}{c}0.0832 * * * \\
(0.0173)\end{array}$ & $\begin{array}{c}0.0807^{* * *} \\
(0.0172)\end{array}$ & & $\begin{array}{c}0.129 * * * \\
(0.0329)\end{array}$ & $\begin{array}{c}0.123 * * * \\
(0.0327)\end{array}$ \\
\hline$\%$ Whites & & $\begin{array}{c}-0.0188 * * \\
(0.0075)\end{array}$ & $\begin{array}{c}-0.0173 * * \\
(0.0074)\end{array}$ & & $\begin{array}{c}-0.0249 * * * \\
(0.0043)\end{array}$ & $\begin{array}{c}-0.0235 * * * \\
(0.0043)\end{array}$ & & $\begin{array}{c}-0.0926 * * * \\
(0.0084)\end{array}$ & $\begin{array}{c}-0.0896 * * * \\
(0.0082)\end{array}$ \\
\hline$\%$ Immigrants & & $\begin{array}{c}0.122 * * * \\
(0.0236)\end{array}$ & $\begin{array}{c}0.124 * * * \\
(0.0232)\end{array}$ & & $\begin{array}{c}0.0228^{* *} \\
(0.0108)\end{array}$ & $\begin{array}{c}0.0239 * * \\
(0.0108)\end{array}$ & & $\begin{array}{l}-0.0099 \\
(0.0209)\end{array}$ & $\begin{array}{l}-0.0076 \\
(0.0203)\end{array}$ \\
\hline Wage Tax & & $\begin{array}{l}-0.0456 \\
(0.0636)\end{array}$ & $\begin{array}{l}-0.0436 \\
(0.0634)\end{array}$ & & $\begin{array}{c}0.0630 \\
(0.0407)\end{array}$ & $\begin{array}{c}0.0633 \\
(0.0402)\end{array}$ & & $\begin{array}{c}0.0052 \\
(0.0799)\end{array}$ & $\begin{array}{c}0.0058 \\
(0.0790)\end{array}$ \\
\hline Color & & $\begin{array}{c}-0.0028^{* * *} \\
(0.0011)\end{array}$ & $\begin{array}{c}-0.0028^{* * *} \\
(0.0011)\end{array}$ & & $\begin{array}{c}-0.0025^{* * *} \\
(0.0007)\end{array}$ & $\begin{array}{c}-0.0025 * * * \\
(0.0007)\end{array}$ & & $\begin{array}{c}-0.0029 * * \\
(0.0015)\end{array}$ & $\begin{array}{c}-0.0029 * * \\
(0.0015)\end{array}$ \\
\hline \% Democrats (House) & & $\begin{array}{l}0.0127^{*} \\
(0.0068)\end{array}$ & $\begin{array}{l}0.0126 * \\
(0.0069)\end{array}$ & & $\begin{array}{c}0.0085^{* *} \\
(0.0040)\end{array}$ & $\begin{array}{c}0.0084^{* *} \\
(0.0040)\end{array}$ & & $\begin{array}{c}0.0046 \\
(0.0081)\end{array}$ & $\begin{array}{c}0.0047 \\
(0.0081)\end{array}$ \\
\hline January Temperature & & $\begin{array}{c}0.0008 * * * \\
(0.0002)\end{array}$ & $\begin{array}{c}0.0008 * * * \\
(0.0002)\end{array}$ & & $\begin{array}{c}0.0005 * * * \\
(0.0001)\end{array}$ & $\begin{array}{c}0.0005^{* * *} \\
(0.0001)\end{array}$ & & $\begin{array}{c}0.0008 * * * \\
(0.0002)\end{array}$ & $\begin{array}{c}0.0008 * * * \\
(0.0002)\end{array}$ \\
\hline Constant & $0.0768 * * *$ & 0.0252 & $0.0313^{*}$ & $0.0316^{* * *}$ & $0.0358 * *$ & 0.0189 & $0.114^{* * *}$ & $0.187^{* * *}$ & $0.175^{* * *}$ \\
\hline
\end{tabular}




\begin{tabular}{|c|c|c|c|c|c|c|c|c|c|}
\hline & $(0.0031)$ & $(0.0264)$ & $(0.0179)$ & $(0.0020)$ & $(0.0163)$ & $(0.0124)$ & $(0.0038)$ & $(0.0324)$ & $(0.0234)$ \\
\hline Year FE & $Y$ & $Y$ & $Y$ & Y & $Y$ & $Y$ & Y & $Y$ & Y \\
\hline State FE & $Y$ & $Y$ & $Y$ & Y & $\mathrm{Y}$ & $Y$ & Y & $\mathrm{Y}$ & Y \\
\hline Observations & 1,702 & 1,490 & 1,490 & 2,075 & 1,590 & 1,590 & 2,079 & 1,594 & 1,594 \\
\hline R-squared & 0.820 & 0.816 & 0.817 & 0.701 & 0.687 & 0.689 & 0.736 & 0.771 & 0.773 \\
\hline
\end{tabular}

Note: Robust standard errors in parentheses $* * * p<0.01,{ }^{* *} p<0.05, * p<0.1$ All regressions are weighted by the MSA population. 
[Table III] MSA Unemployment 90-11 (BLS)

\begin{tabular}{l|c|c|c}
\hline & \multicolumn{3}{|c}{ BLS Total Unemployment } \\
\hline R-Squared & 0.5963 & 0.2439 & 0.8398 \\
\hline MSA FE & Y & $\mathrm{N}$ & $\mathrm{Y}$ \\
Year FE & $\mathrm{N}$ & $\mathrm{Y}$ & $\mathrm{Y}$ \\
\hline \hline No. Obs & 6622 & 6622 & 6622 \\
\hline
\end{tabular}

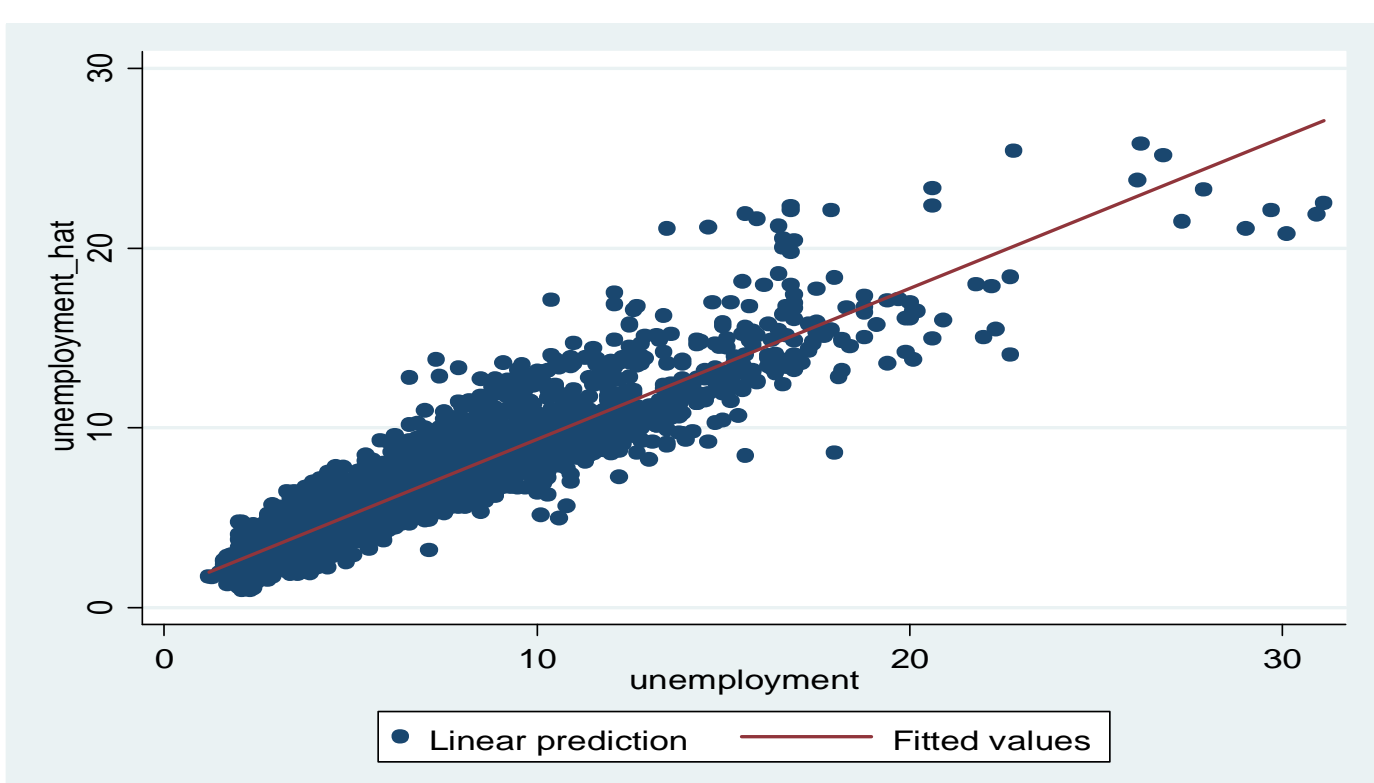

[Figure I] Actual MSA unemployment \& predicted MSA unemployment

[Table IV] MSA Unemployment 90, 00, 05-11

\begin{tabular}{l|c|c|c|c}
\hline & $\begin{array}{c}\text { BLS Total } \\
\text { Unemployment }\end{array}$ & $\begin{array}{c}\text { Census /ACS Total } \\
\text { Unemployment }\end{array}$ & $\begin{array}{c}\text { Census/ACS } \\
\text { College } \\
\text { Unemployment }\end{array}$ & $\begin{array}{c}\text { Census/ ACS } \\
\text { Non-College } \\
\text { Unemployment }\end{array}$ \\
\hline \hline R-Squared & 0.8856 & 0.7633 & 0.6094 & 0.7424 \\
\hline MSA FE & $Y$ & $Y$ & $Y$ & $Y$ \\
Year FE & $Y$ & $Y$ & $Y$ & $Y$ \\
\hline \hline No. Obs & 2178 & 2649 & 2649 & 2649 \\
\hline
\end{tabular}


[Table V] MSA Unemployment Fixed Effect

\begin{tabular}{|c|c|c|c|c|c|c|c|c|c|}
\hline \multirow[b]{2}{*}{ VARIABLES } & \multicolumn{3}{|c|}{ Fixed9011 } & \multicolumn{3}{|c|}{ College Fixed9011 } & \multicolumn{3}{|c|}{ Non-College Fixed9011 } \\
\hline & (1) & (2) & (3) & (4) & (5) & (6) & (7) & (8) & (9) \\
\hline$\%$ College Graduate_80 & $\begin{array}{c}-0.0722^{* * *} \\
(0.0249)\end{array}$ & $\begin{array}{c}-0.123^{* * *} \\
(0.0258)\end{array}$ & $\begin{array}{c}-0.119 * * * \\
(0.0260)\end{array}$ & $\begin{array}{l}-0.0094 \\
(0.0141)\end{array}$ & $\begin{array}{c}-0.0417^{* * *} \\
(0.0150)\end{array}$ & $\begin{array}{c}-0.0403^{* *} \\
(0.0163)\end{array}$ & $\begin{array}{c}-0.0869 * * * \\
(0.0224)\end{array}$ & $\begin{array}{c}-0.117^{* * *} \\
(0.0284)\end{array}$ & $\begin{array}{c}-0.117^{* * *} \\
(0.0303)\end{array}$ \\
\hline Portfolio Diversity_89 & & $\begin{array}{l}-0.0011 \\
(0.0016)\end{array}$ & & & $\begin{array}{l}-0.0009 \\
(0.0009)\end{array}$ & & & $\begin{array}{l}-0.0030 \\
(0.0021)\end{array}$ & \\
\hline Nation Diversity_89 & & & $\begin{array}{c}0.0010 \\
(0.0007)\end{array}$ & & & $\begin{array}{c}0.0004 \\
(0.0004)\end{array}$ & & & $\begin{array}{c}0.0004 \\
(0.0006)\end{array}$ \\
\hline$\%$ Heads_80 & & $\begin{array}{c}0.0674 \\
(0.0915)\end{array}$ & $\begin{array}{c}0.0530 \\
(0.0917)\end{array}$ & & $\begin{array}{l}0.115^{* *} \\
(0.0501)\end{array}$ & $\begin{array}{l}0.110^{* *} \\
(0.0500)\end{array}$ & & $\begin{array}{c}0.0825 \\
(0.0863)\end{array}$ & $\begin{array}{c}0.0723 \\
(0.0906)\end{array}$ \\
\hline$\%$ Owners_80 & & $\begin{array}{c}0.0966 * * * \\
(0.0303)\end{array}$ & $\begin{array}{c}0.0960^{* * *} \\
(0.0305)\end{array}$ & & $\begin{array}{c}0.0364 * * \\
(0.0140)\end{array}$ & $\begin{array}{c}0.0359 * * \\
(0.0141)\end{array}$ & & $\begin{array}{c}0.0837^{* *} \\
(0.0398)\end{array}$ & $\begin{array}{c}0.0820 * * \\
(0.0404)\end{array}$ \\
\hline$\%$ Age $50+\_80$ & & $\begin{array}{l}-0.114^{* *} \\
(0.0482)\end{array}$ & $\begin{array}{l}-0.109 * * \\
(0.0475)\end{array}$ & & $\begin{array}{l}-0.0300 \\
(0.0239)\end{array}$ & $\begin{array}{l}-0.0283 \\
(0.0244)\end{array}$ & & $\begin{array}{l}-0.0638 \\
(0.0516)\end{array}$ & $\begin{array}{l}-0.0629 \\
(0.0540)\end{array}$ \\
\hline$\%$ Whites_80 & & $\begin{array}{c}0.0176 \\
(0.0180)\end{array}$ & $\begin{array}{c}0.0193 \\
(0.0186)\end{array}$ & & $\begin{array}{c}-0.0021 \\
(0.00860)\end{array}$ & $\begin{array}{c}-0.0008 \\
(0.00925)\end{array}$ & & $\begin{array}{c}-0.0579 * * * \\
(0.0199)\end{array}$ & $\begin{array}{c}-0.0541^{* * *} \\
(0.0206)\end{array}$ \\
\hline \% Immigrants_80 & & $\begin{array}{c}0.176^{* * *} \\
(0.0473)\end{array}$ & $\begin{array}{c}0.178 * * * \\
(0.0473)\end{array}$ & & $\begin{array}{c}0.130 * * * \\
(0.0192)\end{array}$ & $\begin{array}{c}0.132 * * * \\
(0.0197)\end{array}$ & & $\begin{array}{c}0.168^{* * *} \\
(0.0595)\end{array}$ & $\begin{array}{c}0.170 * * * \\
(0.0617)\end{array}$ \\
\hline Wage Tax_89 & & $\begin{array}{c}0.125^{* * *} \\
(0.0371)\end{array}$ & $\begin{array}{c}0.120 * * * \\
(0.0366)\end{array}$ & & $\begin{array}{l}0.0322 * \\
(0.0194)\end{array}$ & $\begin{array}{c}0.0293 \\
(0.0198)\end{array}$ & & $\begin{array}{c}0.0937^{* *} \\
(0.0441)\end{array}$ & $\begin{array}{l}0.0859 * \\
(0.0463)\end{array}$ \\
\hline Blue_89 & & $\begin{array}{c}0.0107 * * * \\
(0.0035)\end{array}$ & $\begin{array}{c}0.0118^{* * *} \\
(0.0033)\end{array}$ & & $\begin{array}{c}0.0037^{* *} \\
(0.0016)\end{array}$ & $\begin{array}{c}0.0042^{* * *} \\
(0.0016)\end{array}$ & & $\begin{array}{c}0.0163^{* * *} \\
(0.0041)\end{array}$ & $\begin{array}{c}0.0174 * * * \\
(0.0040)\end{array}$ \\
\hline Purple_89 & & $\begin{array}{c}0.0074^{* *} \\
(0.0030)\end{array}$ & $\begin{array}{c}0.0079 * * * \\
(0.0029)\end{array}$ & & $\begin{array}{c}0.0016 \\
(0.0013)\end{array}$ & $\begin{array}{c}0.0017 \\
(0.0014)\end{array}$ & & $\begin{array}{c}0.0067^{* *} \\
(0.0031)\end{array}$ & $\begin{array}{c}0.0070 * * \\
(0.0033)\end{array}$ \\
\hline \% Democrats (House)_89 & & $\begin{array}{c}0.0383^{* * *} \\
(0.0125)\end{array}$ & $\begin{array}{c}0.0380^{* * *} \\
(0.0125)\end{array}$ & & $\begin{array}{c}0.0091 \\
(0.0085)\end{array}$ & $\begin{array}{c}0.0096 \\
(0.0091)\end{array}$ & & $\begin{array}{c}0.0220 \\
(0.0158)\end{array}$ & $\begin{array}{c}0.0234 \\
(0.0173)\end{array}$ \\
\hline January Temperature_89 & & $\begin{array}{c}0.0001 \\
(0.0002)\end{array}$ & $\begin{array}{c}0.0001 \\
(0.0002)\end{array}$ & & $\begin{array}{c}0.00003 \\
(0.00007)\end{array}$ & $\begin{array}{c}0.00002 \\
(0.00007)\end{array}$ & & $\begin{array}{l}-0.0003 \\
(0.0002)\end{array}$ & $\begin{array}{l}-0.0003 \\
(0.0002)\end{array}$ \\
\hline Constant & $0.0412^{* * *}$ & -0.0426 & $-0.0704 * * *$ & $0.0109 * * *$ & -0.0316 & $-0.0558^{* * *}$ & $0.0608 * * *$ & 0.0985 & 0.0224 \\
\hline
\end{tabular}




\begin{tabular}{|c|c|c|c|c|c|c|c|c|c|}
\hline & $(0.0077)$ & $(0.0497)$ & $(0.0250)$ & $(0.0040)$ & $(0.0253)$ & $(0.0150)$ & $(0.0077)$ & $(0.0690)$ & $(0.0326)$ \\
\hline Observations & 190 & 179 & 179 & 235 & 199 & 199 & 235 & 199 & 199 \\
\hline R-squared & 0.094 & 0.466 & 0.469 & 0.005 & 0.592 & 0.590 & 0.096 & 0.465 & 0.456 \\
\hline
\end{tabular}

Note: Robust standard errors in parentheses $* * * p<0.01, * * p<0.05, * p<0.1$ All regressions are weighted by the MSA population.

[Table VI] MSA Average Wage

\begin{tabular}{|c|c|c|c|c|c|c|c|c|c|}
\hline \multirow[b]{2}{*}{ VARIABLES } & \multicolumn{3}{|c|}{ Avg. Wage } & \multicolumn{3}{|c|}{ College Avg. Wage } & \multicolumn{3}{|c|}{ Non-Collage Avg. Wage } \\
\hline & $(1)$ & $(2)$ & (3) & $(4)$ & $(5)$ & $(6)$ & $(7)$ & $(8)$ & (9) \\
\hline \% College Graduate & $\begin{array}{c}1.674^{* * *} \\
(0.0338)\end{array}$ & $\begin{array}{c}1.216^{* * *} \\
(0.0503)\end{array}$ & $\begin{array}{c}1.225^{* * *} \\
(0.0512)\end{array}$ & $\begin{array}{c}1.268^{* * *} \\
(0.0366)\end{array}$ & $\begin{array}{c}0.766^{* * *} \\
(0.0541)\end{array}$ & $\begin{array}{c}0.767^{* * *} \\
(0.0551)\end{array}$ & $\begin{array}{c}0.751 * * * \\
(0.0358)\end{array}$ & $\begin{array}{c}0.413^{* * *} \\
(0.0503)\end{array}$ & $\begin{array}{c}0.427^{* * *} \\
(0.0516)\end{array}$ \\
\hline Portfolio Diversity & & $\begin{array}{c}0.0041 \\
(0.0033)\end{array}$ & & & $\begin{array}{c}0.0032 \\
(0.0035)\end{array}$ & & & $\begin{array}{c}0.0031 \\
(0.0034)\end{array}$ & \\
\hline Nation Diversity & & & $\begin{array}{c}0.0019 \\
(0.0020)\end{array}$ & & & $\begin{array}{c}0.0002 \\
(0.0021)\end{array}$ & & & $\begin{array}{c}0.0029 \\
(0.0024)\end{array}$ \\
\hline$\%$ Heads & & $\begin{array}{c}1.001^{* * *} \\
(0.186)\end{array}$ & $\begin{array}{c}0.986 * * * \\
(0.187)\end{array}$ & & $\begin{array}{c}0.677^{* * *} \\
(0.202)\end{array}$ & $\begin{array}{c}0.675^{* * *} \\
(0.203)\end{array}$ & & $\begin{array}{c}1.172^{* * *} \\
(0.188)\end{array}$ & $\begin{array}{c}1.149 * * * \\
(0.187)\end{array}$ \\
\hline$\%$ Owners & & $\begin{array}{c}0.699 * * * \\
(0.0823)\end{array}$ & $\begin{array}{c}0.698 * * * \\
(0.0827)\end{array}$ & & $\begin{array}{c}0.713^{* * *} \\
(0.0842)\end{array}$ & $\begin{array}{c}0.714^{* * *} \\
(0.0849)\end{array}$ & & $\begin{array}{c}0.651 * * * \\
(0.0810)\end{array}$ & $\begin{array}{c}0.649 * * * \\
(0.0809)\end{array}$ \\
\hline$\%$ Age $50+$ & & $\begin{array}{c}-0.252 * * * \\
(0.0976)\end{array}$ & $\begin{array}{c}-0.250 * * \\
(0.0977)\end{array}$ & & $\begin{array}{c}-0.0410 \\
(0.108)\end{array}$ & $\begin{array}{c}-0.0414 \\
(0.108)\end{array}$ & & $\begin{array}{c}-0.622 * * * \\
(0.103)\end{array}$ & $\begin{array}{c}-0.619 * * * \\
(0.103)\end{array}$ \\
\hline$\%$ Whites & & $\begin{array}{c}-0.523 * * * \\
(0.0340)\end{array}$ & $\begin{array}{c}-0.526 * * * \\
(0.0344)\end{array}$ & & $\begin{array}{c}-0.523 * * * \\
(0.0378)\end{array}$ & $\begin{array}{c}-0.523 * * * \\
(0.0381)\end{array}$ & & $\begin{array}{c}-0.423^{* * *} \\
(0.0337)\end{array}$ & $\begin{array}{c}-0.428 * * * \\
(0.0341)\end{array}$ \\
\hline$\%$ Immigrants & & $\begin{array}{c}0.503 * * * \\
(0.0979)\end{array}$ & $\begin{array}{c}0.497^{* * *} \\
(0.0981)\end{array}$ & & $\begin{array}{c}0.798 * * * \\
(0.111)\end{array}$ & $\begin{array}{c}0.796^{* * *} \\
(0.111)\end{array}$ & & $\begin{array}{c}0.133 \\
(0.0875)\end{array}$ & $\begin{array}{c}0.125 \\
(0.0877)\end{array}$ \\
\hline Wage Tax & & $\begin{array}{c}-0.286 \\
(0.224)\end{array}$ & $\begin{array}{c}-0.298 \\
(0.226)\end{array}$ & & $\begin{array}{c}-0.0707 \\
(0.245)\end{array}$ & $\begin{array}{r}-0.0770 \\
(0.245)\end{array}$ & & $\begin{array}{c}-0.413^{*} \\
(0.221)\end{array}$ & $\begin{array}{c}-0.426 * \\
(0.224)\end{array}$ \\
\hline Color & & $\begin{array}{c}0.0010 \\
(0.0026)\end{array}$ & $\begin{array}{c}0.0009 \\
(0.0026)\end{array}$ & & $\begin{array}{c}0.0028 \\
(0.0030)\end{array}$ & $\begin{array}{c}0.0028 \\
(0.0030)\end{array}$ & & $\begin{array}{c}0.0023 \\
(0.0028)\end{array}$ & $\begin{array}{c}0.0022 \\
(0.0028)\end{array}$ \\
\hline \% Democrats (House) & & $\begin{array}{c}0.0091 \\
(0.0060)\end{array}$ & $\begin{array}{c}0.0090 \\
(0.0060)\end{array}$ & & $\begin{array}{c}0.0192 * * \\
(0.0077)\end{array}$ & $\begin{array}{c}0.0190 * * \\
(0.0076)\end{array}$ & & $\begin{array}{c}-0.0045 \\
(0.0071)\end{array}$ & $\begin{array}{l}-0.0045 \\
(0.0070)\end{array}$ \\
\hline January Temperature & & $\begin{array}{l}0.0012 * \\
(0.0008)\end{array}$ & $\begin{array}{c}0.0012 \\
(0.0008)\end{array}$ & & $\begin{array}{c}0.0016 * * \\
(0.0008)\end{array}$ & $\begin{array}{l}0.0016^{*} \\
(0.0008)\end{array}$ & & $\begin{array}{c}0.0010 \\
(0.0007)\end{array}$ & $\begin{array}{c}0.0010 \\
(0.0007)\end{array}$ \\
\hline Constant & $\begin{array}{c}9.586 * * * \\
(0.0131)\end{array}$ & $\begin{array}{c}9.123^{* * *} \\
(0.107)\end{array}$ & $\begin{array}{c}9.237^{* * *} \\
(0.0861)\end{array}$ & $\begin{array}{c}9.985 * * * \\
(0.0153)\end{array}$ & $\begin{array}{c}9.593 * * * \\
(0.116)\end{array}$ & $\begin{array}{c}9.677^{* * *} \\
(0.0945)\end{array}$ & $\begin{array}{c}9.640 * * * \\
(0.0137)\end{array}$ & $\begin{array}{c}9.172 * * * \\
(0.120)\end{array}$ & $\begin{array}{c}9.262 * * * \\
(0.0813)\end{array}$ \\
\hline
\end{tabular}




\begin{tabular}{l|ccc|ccc|ccc} 
Year FE & $Y$ & $Y$ & $Y$ & $Y$ & $Y$ & $Y$ & $Y$ & $Y$ \\
State FE & $Y$ & $Y$ & $Y$ & $Y$ & $Y$ & $Y$ & $Y$ & $Y$ & $Y$ \\
Observations & 2,627 & 2,066 & 2,066 & 2,627 & 2,066 & 2,066 & 2,627 & 2,066 & 2,066 \\
R-squared & 0.894 & 0.927 & 0.927 & 0.846 & 0.903 & 0.903 & 0.821 & 0.873 & 0.873 \\
\hline
\end{tabular}


[Table VII] MSA Average House Value

\begin{tabular}{|c|c|c|c|}
\hline \multirow[b]{2}{*}{ VARIABLES } & \multicolumn{3}{|c|}{ Avg. House Value } \\
\hline & (1) & (2) & (3) \\
\hline \% College Graduate & $\begin{array}{c}3.112^{* * *} \\
(0.0782)\end{array}$ & $\begin{array}{c}2.556^{* * *} \\
(0.148)\end{array}$ & $\begin{array}{c}2.529 * * * \\
(0.150)\end{array}$ \\
\hline Portfolio Diversity & & $\begin{array}{c}0.0006 \\
(0.0100)\end{array}$ & \\
\hline Nation Diversity & & & $\begin{array}{l}-0.0061 \\
(0.0040)\end{array}$ \\
\hline$\%$ Heads & & $\begin{array}{c}-0.924^{*} \\
(0.496)\end{array}$ & $\begin{array}{c}-0.875^{*} \\
(0.500)\end{array}$ \\
\hline$\%$ Owners & & $\begin{array}{c}-0.461^{*} \\
(0.262)\end{array}$ & $\begin{array}{c}-0.454^{*} \\
(0.264)\end{array}$ \\
\hline$\%$ Age $50+$ & & $\begin{array}{c}1.585^{* * *} \\
(0.293)\end{array}$ & $\begin{array}{c}1.576 * * * \\
(0.294)\end{array}$ \\
\hline$\%$ Whites & & $\begin{array}{c}-0.268 * * * \\
(0.0996)\end{array}$ & $\begin{array}{c}-0.258^{* *} \\
(0.100)\end{array}$ \\
\hline$\%$ Immigrants & & $\begin{array}{c}1.749 * * * \\
(0.308)\end{array}$ & $\begin{array}{c}1.763^{* * *} \\
(0.310)\end{array}$ \\
\hline Wage Tax & & $\begin{array}{c}0.335 \\
(0.691)\end{array}$ & $\begin{array}{c}0.351 \\
(0.690)\end{array}$ \\
\hline Color & & $\begin{array}{c}0.0151 \\
(0.0095)\end{array}$ & $\begin{array}{c}0.0152 \\
(0.0095)\end{array}$ \\
\hline \% Democrats (House) & & $\begin{array}{l}-0.0127 \\
(0.0311)\end{array}$ & $\begin{array}{l}-0.0133 \\
(0.0309)\end{array}$ \\
\hline January Temperature & & $\begin{array}{c}-0.0047^{* *} \\
(0.0022)\end{array}$ & $\begin{array}{c}-0.0047^{* *} \\
(0.0022)\end{array}$ \\
\hline Constant & $\begin{array}{c}10.39 * * * \\
(0.0356) \\
\end{array}$ & $\begin{array}{c}11.24^{* * *} \\
(0.348) \\
\end{array}$ & $\begin{array}{c}11.24 * * * \\
(0.236) \\
\end{array}$ \\
\hline Year FE & $Y$ & $Y$ & $Y$ \\
\hline State FE & Y & $\mathrm{Y}$ & $Y$ \\
\hline Observations & 2,627 & 2,066 & 2,066 \\
\hline R-squared & 0.837 & 0.872 & 0.872 \\
\hline
\end{tabular}

All regressions are weighted by the MSA population. 